\title{
ユビキタス環境における実空間モニタリング手法
}

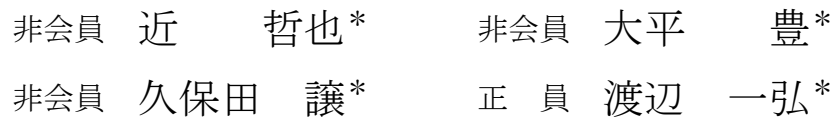

\section{Real Space Monitoring Technique in Ubiquitous Environments}

Tetsuya Kon*, Non-member, Yutaka Ohira*, Non-member,

Yuzuru Kubota*, Non-member, Kazuhiro Watanabe*, Member

\begin{abstract}
A method of a monitoring and remote controlling real world have been described by using a VRML/Java based virtual reality space which contains multimedia elements, intended for the development of a ubiquitous monitoring system. The focuses are given on the improvements for currently used, static virtual reality spaces to be more capable of an interactive function through which users can bilaterally monitor or control the real world. The monitoring is realized by reflecting sensing data from sensors which were placed in the real space onto a virtual reality space. Remote control can be realized by sending commands to actuators through the 3-D space. Additionally, the virtual reality space has been created as a Web page. So that the multiple users can access the system at the same time. The developed system has shown the availability for such applications as robot navigation, management of buildings and monitoring of factories and environments. In this paper, the construction method of the new technique of the real space monitoring and its operation experiment are described which can put in view a full-scall ubiquitous environment. The extendibility and possibility for monitoring are also described which could provide essential ubiquitous environments.
\end{abstract}

キーワード : ユビキタス, バーチャルリアリティ，3D，モニタリング

Keywords : ubiquitous, virtual reality, 3D, monitoring

\section{1. はじめに}

ユビキタス環境とは，あらゆるものにコンピュータが埋 め込まれている環境である。今日では，人間が小型なコン ピュータ $(\mathrm{PDA}$ や携帯電話など)を持ち運ぶ環境もユビキタ スの一環であるともとらえられてきている。各種ネットワ ーク上にあるコンピュータはLANやインターネットなどを 介して結ばれており，ある特定の知的機能を持つことが考 えられる。ユビキタス環境におけるコンピュータは，ユー ザが個人で所有するだけのものではなく，多くのユーザが ネットワーク上のコンピュータを共有するといった概念が 生まれることになる。ユーザは時と場所を選ばずにネット ワークから必要とする情報を選んで取り出してくることが できるという意味から, “いつでもどこでも”といったユビ キタスの第一義的な意味が与えられている。

さらに本格的概念として, あらゆるものに CPUを内在す

* 創価大学工学部

不192-8577 東京都八王子市丹木町 1-236

Faculty of Engineering, SOKA University,

1-236 Tangi-cho, Hachioji-shi, Tokyo 192-8577
ることにより，それらが知的機能を持ったインテリジェン 卜な存在になるということが言われている。インテリジェ ントなものは, 自分の能力や周囲の環境を認識して特定の 知的機能を果たすことが可能となってくる。その知的機能 は状況に応じて変更され得るもので, 時にはユーザ自身に より，また他のコンピュータによって，さらには温度や時 間などのセンサ情報に対して，豊富な情報を利用して知的 機能を創出するようになるであろう。コンピュータを利用 するユーザが存在しなくとも, コンピュータ自身がネット ワークから情報を取得して最適な知的機能を果たすことも 考えられ, コンピュータ (CPU)が偏在するという本格的なユ ビキタスシステムへと発展すると考えられる。

本研究室では実空間モニタリングと実空間の制御の新し い手法の構築と運用実験を行っている。これは, 実空間に 設置するセンサからの情報を自動的にリアルタイムでバー チャルリアリティ空間に反映すると同時に, ユーザからバ ーチャルリアリティ空間にアクセス寸ることで実空間の特 定の情況に変化を与えられるものである。このバーチャル リアリティはWebページとして作成し，センサからの情報 
が蓄積される Web サーバ上に置いている。ユーザは時や場 所を選ばずに，バーチャルリアリティにアクセスすること でモニタリングを行うことができる。その意味において， 本手法はユビキタス環境の一端としてとらえることができ る。図 1 は本手法の概念を示している。

本手法を本来のユビキタスの概念に基づいて論議を展開 する。モニタリングで使用するセンサ群は，コンピュータ を持つインテリジェントなものになる。自律移動ロボット は，もともとインテリジェントな存在であり，モニタリン グの対象でもあり, 同時にユーザとしても位置づけられる。 インテリジェントなセンサや自律移動ロボットはある特定 の知的機能を持つ。インテリジェントなセンサは，ただ単 に情報を取得するだけのものではなくなり，取得した情報 をバーチャルリアリティに配信することや，バーチャルリ アリティにアクセスして他のセンサからの情報を取得して 特定の知的機能を果たすことが可能となる。自律移動ロボ ットは，搭載しているセンサが取得することができない情 報を，バーチャルリアリティから取得することができる。 自律移動ロボットやセンサは数值情報で空間を認識するこ とができる。しかし，人間は数值の羅列やある程度の表示 では複雑な状況をモニタリングすることが困難な場合もあ り，何らかの表示インタフェースが必要と考えられる。そ こで，本手法では人間が視覚的に理解しやすく，モニタリ ングすべき空間の特定の情報をリアルタイムベースに再現 したバーチャルリアリティを用いることを提案している。 つまり，人間，自律移動ロボット，知的センサ群の連携を 支援するための共有のプラットフォームとしての可能性を 検討している。

今日では，バーチャルリアリティを用いたモニタリング 手法に関する研究が進んでいる(1)。その手法の多くはシステ ムを利用する対象(センサ情報を利用するユーザ)が人間に のみ限定され，バーチャルリアリティは人間のための表示 インタフェースとして利用されている。前述したように,

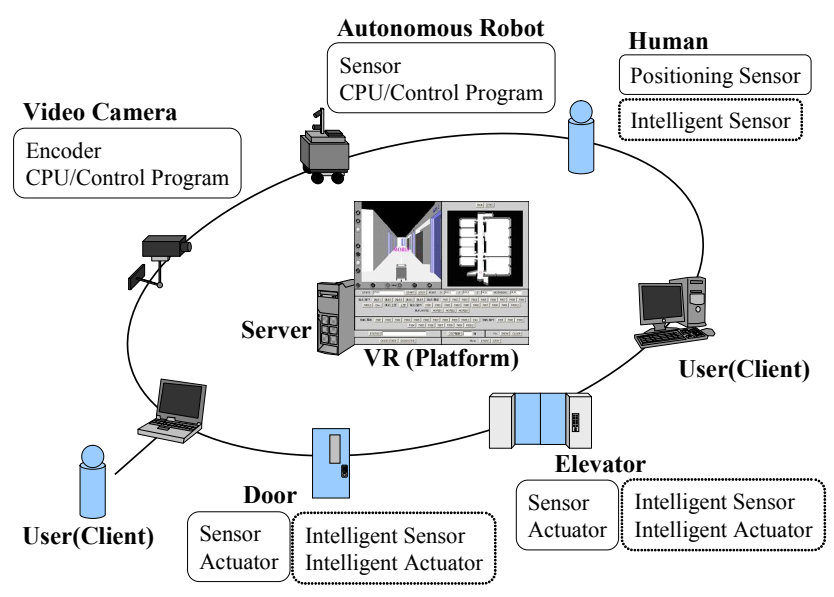

図 1 本手法の概念図

Fig. 1. Concept chart of this technique.
本手法ではバーチャルリアリティを人間に対する表示イン タフェースとして扱うと同時に，自律移動ロボットや知的 センサなどが情報を共有し，何らかの連携支援をする場と しての試みを行っている。

このようなシステムにおける前提条件としては，利用の ユビキタス性の観点から, LAN やインターネット(Web)上 で動作することが必要である。また, さらに要求される条 件・課題として，(1)実空間のセンサ情報のバーチャルリア リティへの反映, (2)人間のバーチャルリアリティを介して の実空間アクセス, (3)リアルタイムな情報の反映, (4)シス テムとバーチャルリアリティの操作性, (5)センサ情報を持 たない突発的な人間・物の侵入に対する情報取りこみ，な ゼが挙げられる。

本論文では，ユビキタス環境を視野に入れた実空間モニ タリングの新しい手法の構築法と運用実験について述べる とともに，本格的なユビキタス環境を備えたモニタリング への拡張性と可能性について述べる。

\section{2. 双方向バーチャルリアリティ空間の概要}

本手法ではプラットフォームとするバーチャルリアリテ イを構築するためにVRML2.0(97)用いている。このバーチ ヤルリアリティは, 時や場所を選ばないモニタリング手法 を構築するために Web ページとして構築している。

センサや自律移動ロボットからの情報は, 制御プログラ ムによって Web サーバに集約される。ユーザがネットワー クを介して Web サーバにアクセスすると, バーチャルリア リティ空間ではセンサ群・自律移動ロボットからの情報を 自動的にリアルタイムで反映しているので，モニタリング を行うことができる。また，アクチュエータ駆動のための 制御プログラムにバーチャルリアリティを介して情報を配 信することで，リモートコントロールを行うことができる。 クライアント・サーバ間のデータ通信は Socket $(\langle 3 \cdot 1 \cdot 3\rangle$ 参照)を用いて行っている。

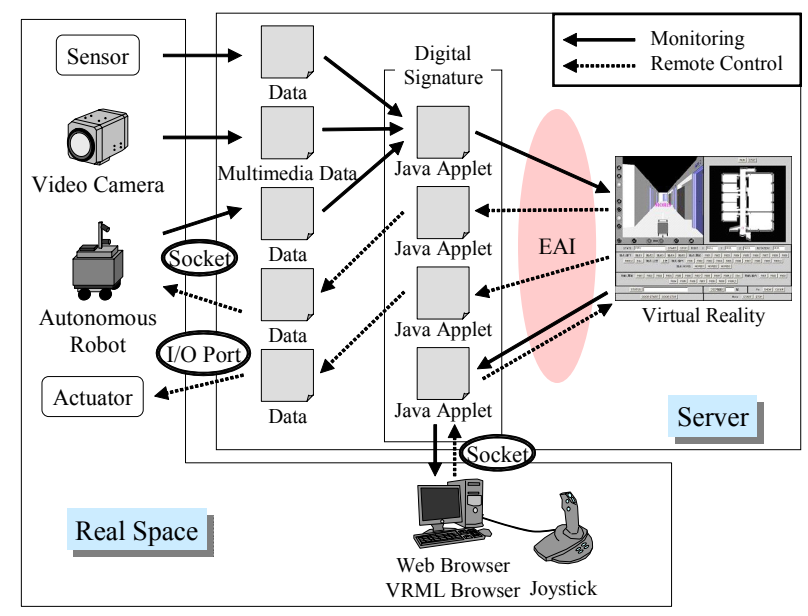

図 2 システム構成図

Fig. 2. System configuration. 
本手法では，Java 言語を用いて実空間とバーチャルリア リティ空間における情報の連携を行っている。Java 言語で 作成したプログラムは通信以外にモニタリング表示機能の ためのものもあり, それらも Applet としてバーチャルリア リティと同一Webページ上に作成している。

本手法では, 詳細なモニタリングや多彩な表現として, ユーザの要求に応じてバーチャルリアリティにマルチメデ イア・データ(静止画, 動画, 音声)を反映することができる。 動画や音声に関しては, リアルタイムな配信を行うために ストリーミング技術 $(\langle 3 \cdot 1 \cdot 5\rangle$ 参照 $)$ 用いている。

\section{3. システムの構築}

〈3・1〉構築技術図 2 に本システムの構成を示す。 システムを構成する上で要求される条件や課題を解決する 技術要素について, 以下に項目に分けて詳細を述べる。

〈3·1·1〉 バーチャルリアリティ＼cjkstart本手法で用いるバ 一チャルリアリティは，Web 上で利用ができる汎用性の高 いものである必要がある。本手法では，これらの条件を満 たすものとして VRML2.0(97)を用いている。VRML は C 言語や Java 言語などのプログラム言語ではなく, HTML のようなマークアップ言語でもない。これはモデリング言 語であり，3D シーンの記述に使用する言語である。

通常, VRML2.0 で構築したバーチャルリアリティ空間は Web ブラウザと VRML ブラウザによって表示する。今回は, Web ブラウザに Microsoft 社の Internet Explorer を, VRML ブラウザに Parallel Graphics 社の Cortna VRML Clientを用いている。

〈3·1·2〉実空間との融合＼cjkstart前述したように，本手法 ではバーチャルリアリティに実空間の情報の反映や，バー チャルリアリティからの情報の配信を, Web 上での利用と 汎用性を考慮に入れ，Java 言語を用いて行っている。

Java 言語を用いてバーチャルリアリティ(VRML シーン) にアクセスする方法には大別して, JSAI(Java Script Authoring Interface)と EAI(External Authoring Interface)

\section{JSAI}

[Java Script Authoring Interface]

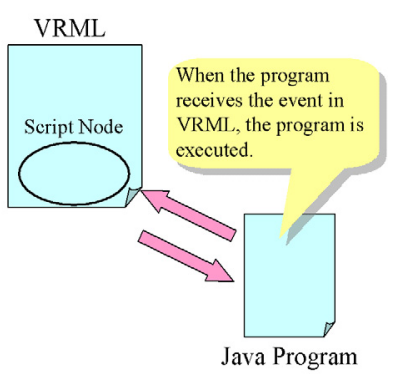

EAI

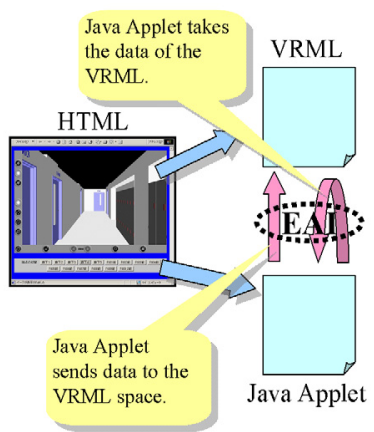

[External Authoring Interface]

図 $3 \mathrm{JSAI}$ とAI の構成図

Fig. 3. Composition chart of JSAI and EAI.
の 2 通りの方法がある。図 3 は JSAI と EAI の構成を示し ている。

JSAI は Java プログラムをVRML の Script ノードから 呼び出す形式をとる。本手法では，プログラム中に Socket を用いたデータ通信を含むため, デジタル署名 $(\langle 3 \cdot 1 \cdot 4\rangle$ 参 照)の技術を用いなければならない。この技術を使用する上 で, Java プログラムをアーカイブファイルに含める必要が ある。しかし, VRMLの Scriptノードはこのアーカイブフ アイル中の Java プログラムを呼び出すことができない。一 方, EAI はVRML シーンを外部スクリプトとして操作する 方式であり, アーカイブファイルを HTML ファイルから呼 び出すことができる。そのため, 本手法では後者の EAI を 用いて実空間とインタラクティブなバーチャルリアリティ の構築を行っている。また, VRML シーンは Web ページ上 で表示しているため, Java プログラムは Java Applet とし て作成を行っている。

〈3·1·3〉 ネットワーク ユーザが本手法を利用して, 実空間のモニタリングを行う際に, 実空間の様々な情報は サーバを介して取得する必要がある。同様に, リモートコ ントロールを行う際にも, ユーザからの命令はサーバを介 して行うことになる。

通常，外部ユーザはサーバに置かれたデータをダウロー ドすることはできるが，アップロードする権利は与えられ ていない。このため, 本手法では, ユーザ・コンピュータ とサーバとのデータ通信に Socket を用いている。 Socket を用いた通信を行うには, サーバ上でユーザからの要求を 待ち受け待機するプログラムの常駐させる必要がある。そ れとともに, ユーザ側で Socketを開き, サーバのポートに アクセス寸るプログラムが必要となる。本手法では, ユー ザ側のプログラムは HTML 上に Java Applet として作成を 行っている。

ネットワーク機能を持ったセンサ・アクチュエータ，ま たは PC 搭載の自律移動ロボットとは上記の Socket 通信に よってデータの取得・配信を行うが，受動的なセンサ等の 場合は直接サーバの I/O ポートもしくは専用インタフェー スを用いることができる。

〈3.1·4〉 デジタル署名ユーザが HTML 上の Java Applet を実行するには，一度プログラムをダウンロードす る必要がある。ダウンロードしたプログラムは Web ブラウ ザによって実行されるが，その際にWeb ブラウザに搭載さ れている Java VM(Virtual Machine)からプログラムに対 して様々な機能制限がかけられる。この機能制限は, プロ グラム内のファイルアクセスやネットワーク接続などの機 能に対してかけられる。本手法では, HTML 上の Java Appletに Socket 通信機能を持つプログラムがあるため,こ の機能制限を解除する必要がある。

機能制限を解除するための技術としてデジタル署名があ る。図 4 はデジタル署名の仕組みを示している。図中のセ キュリティー認証画面というのが, ユーザの機能制限を解 除する際の操作画面である。作成した Java プログラムなど 


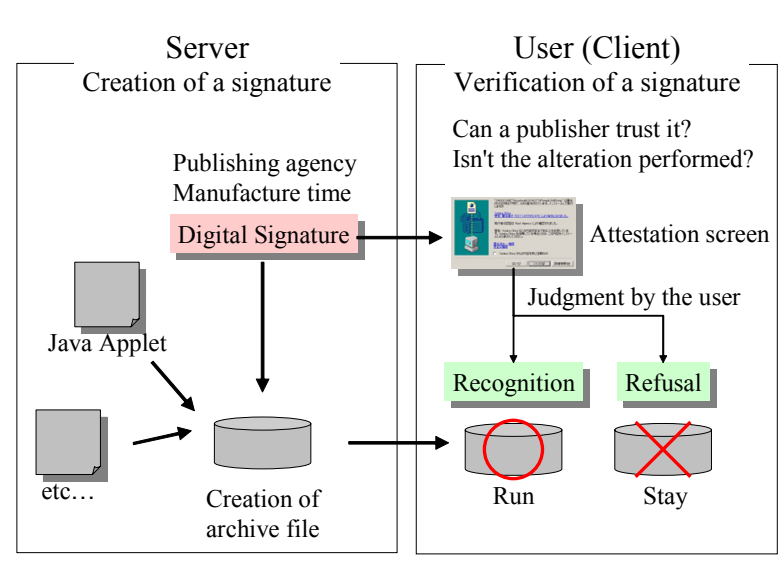

図 4 デジタル署名の仕組み

Fig. 4. Mechanism of digital signature.

のファイルをアーカイブファイルにまとめ, このアーカイ ブファイルに対して，プログラム作成者の個人情報を載せ た署名を付加する。この署名を付加することで，プログラ ムの実行時にユーザに対して制限解除の要求が伝わり，ユ ーザの操作によって制限を解除することができ，プログラ ムを実行することができる。

〈3.1.5〉 マルチメディア·データの融合＼cjkstart前述したよ うに, 本手法ではユーザの要求に応じて, 様々なマルチメ ディア・データをバーチャルリアリティに取り込むことが できる。これは, バーチャルリアリティの表現力の向上を 図るためでもある。マルチメディア・データはユーザの要 求によって表示サイズ，位置などを自由に変更することが できる。

静止画は JPEG 形式と GIF 形式を, 動画と音声はそれぞ れ Real Video, Real Audio 形式としている。各形式は使用 しているVRML ブラウザの対応状況を考慮に入れて採用し ている。静止画は, データサイズも比較的小さいため, リ アルタイム性に問題がなく, VRML でのサポートも行われ ている。動画と音声に関しては, データサイズが膨大なに なるため, リアルタイムな配信を行うために, ストリーミ ング技術を用いている。

本手法では PC にかかる負担を軽減させるために, Real System のストリーミングシステムを用いている。このシス テムは，映像や音声を配信するソフトウェア(Real System Server)が動作するサーバと, 映像や音声を取り込んで RM 形式ファイルを作成するソフトウェア(Real Producer)が動 作するホストを, ネットワークを介した別々の PC を用いる ことができる。

VRML では Real System のライブストリーミングにお けるプロトコル(RTSP)をサポートしていない。そのため, 現段階ではバーチャルリアリティと同一 Web ページ上に表 示を行っている。

〈3.1.6〉操作手法の改善 通常, バーチャルリアリ

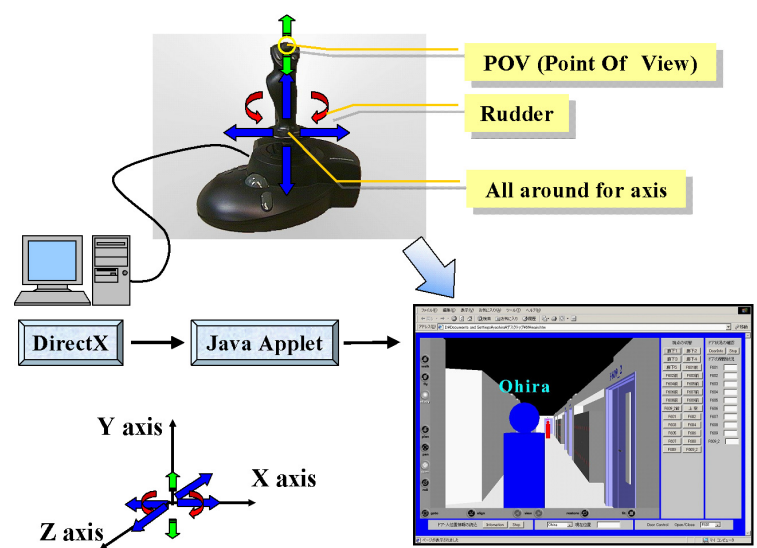

図 5 ジョイスティックとバーチャルリアリティの対応

Fig. 5. Relation of joystick and virtual reality.

ティ内の視点移動はマウスやキーボードを用いて行う。し かし，この操作は慣れていないユーザ(人間)には非常に困難 なものである。バーチャルリアリティ内の操作は容易なも のである必要がある。VRML ブラウザによっては，他の入 力機器による操作がサポートされているが, 独自性が強い ため，詳細な設定を行うのが困難である。

本手法ではバーチャルリアリティ内の操作性を向上する ためにジョイスティックを用いている。作成した Java プロ グラムは様々なバーチャルリアリティ(VRML ファイル)に 対応することができる。ジョイスティックを用いることで, 軸を操作するだけで, マウスなどでバーチャルリアリティ を操作する際の特殊な操作がなくなり, 容易な操作が可能 となる。

図 5 は, ジョイスティックによる操作法の概念と, ジョ イスティックのそれぞれの操作とバーチャルリアリティ内 の視点の動きの対応を示している。ジョイスティックから の入力情報は DirectX を介して Java Applet が受け取る。 受け取った情報は Java Appletによってバーチャルリアリ ティに対応する形式に変換され，視点を変更する。作成し たプログラムでは, ジョイスティックからの情報として, 8 軸情報, rudder(スティックのひねり)情報, POV(Point of View)情報を用いて, バーチャルリアリティ内の視点移動に 適応させている。

〈3·2〉 バーチャルリアリティを用いたモニタリング手 法の運用実験と拡張性現在の主なモニタリング手法と して, 監視カメラを用いた映像によるもの, レーダーなど の 2 次元的なもの, 電光掲示板などの簡易的なものなどが あるが，これらのモニタリング手法にはいくつかのの問題 点が存在する。ビデオカメラを用いた映像によるモニタリ ングでは，全空間をすべてモニターすることは困難でじう しても死角が存在してしまう。また，画像化した空間には 目的とする対象以外の必要のない情報まで含んでしまい, いたずらに情報量が増加する, そして, 複雑な画像から必 
要な情報を識別する画像処理も簡単ではない。2 次元的な モニタリングでは，3 次元的な相互関係が把握できず，情報 量が不足しているため信頼性にそしいといった問題点もあ る。また，電光掲示板などの簡易的なモニタリングでは, 単純化した情報として認識し易い点もあるが，その表現力 の限界もあり，人閒が即座に 3 次元的な空間の出来事を認 識するには困難な場面もある。以上に挙げた従来のモニタ リング手法は, 物理的な配線などで情報が 1 箇所に集約さ れていることが多く, 多人数でのモニタリングや遠隔地か らのモニタリングを考えた場合, 拡張性に乏しい。また, センサやアクチュエータに対して，それぞれに専用の制御 プログラムを実行するコンピュータが設置され，使用目的 や動作が限定されているものが多く，汎用性に乏しい。

本手法は，ユーザが必要とする情報だけをバーチャルリ アリティ空間に反映し, Web を介して遠隔地からでも多ユ 一ザが同時にそれぞれのモニタリング・制御を行うことが 可能なものである。このように, 本手法は他のモニタリン グ手法と比べ，多くの優位な特長を持っている。

現在までに, モニタリング手法の構築として, バーチャ ルリアリティ空間の構築, 及び様々なモニタリング機能を 持つJava プログラムを作成し。バーチャルリアリティを用 いたモニタリングシステムを完成させた。

システムにおける前提条件は LAN やインターネット (Web) 上で動作することである。今回の実験は, ネットワー ク環境として, LAN(ネットワーク間の通信速度は 10[Mbps]) とインターネット上で行い, それぞれのネットワ 一ク環境においてシステムの動作を確認することができ た。

構築したシステムが 1 章で述べたシステムにおける前提 条件, 要求される条件・課題を満たしているかを検証する ために，上記ネットワーク上でいくつかの運用実験を行っ た。

システムの要求条件(1)実空間のセンサ情報のバーチャル リアリティへの反映, (2)人間のバーチャルリアリティを介 しての実空間アクセスの検証を行うために，1)自己位置を 認識するセンサ(本実験ではエンコーダ)とネットワーク機 能が搭載されている自律移動ロボットの位置情報の反映と 遠隔誘導，2)LED（PC のパラレルポートに接続)をアクチ ユエータにみたてた状態監視と点滅制御，について実験を 行った。これらの実験はユーザの操作上は即座に応答し， ほぼリアルタイムに反映とアクセスが確認された。

次に, (3)リアルタイムな情報の反映の検証に関して述べ る。自律移動ロボット上の位置認識センサが情報を取得し てWeb サーバに配信完了する時間間隔は 50[ms], バーチャ ルリアリティへ情報を反映する時間間隔は $50[\mathrm{~ms}]$ で行っ た。情報通信の 1 周期あたりの処理時間が比較的に短いた め, 自律移動ロボットのリアルタイムな情報の反映が行え ていると考えている。実験時の自律移動ロボットの走行速

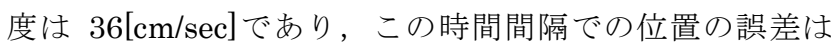
$10[\mathrm{~cm}]$ 程度であり, 自律移動ロボットをモニタリングする
には十分と考えることができる。LED の実験では, 特に応 答速度の計測は行っていないが, 直接パラレルポートから データ取得しているので, 数 $\mathrm{ms}$ 程度かそれ以下と考えてい る。

また, 要求条件(4)システムとバーチャルリアリティの操 作性は次ぎのように確認された。〈3・1・6〉に述べた USB 接 続したジョイスティックを用いて, ジョイスティックの 8 軸情報, rudder 情報, POV 情報をもとに, 様々な視点移動 が可能であることが確認することができた。また，ロボッ トの遠隔誘導についてもスムーズな操作が可能であった。 通常のバーチャルリアリティ空間内における視点移動で使 用するマウスでは, 視点の移動をする方向を変更するのに, その度にユーザによる操作が必要となり, システムの操作 にまで負担がかかってしまっていた。実験において, PCに これにより, バーチャルリアリティのモニタリング・制御 システムとしての操作性を向上できたと考えられる。

最後に, (5)センサ情報を持たない突発的な人間・物の侵 入に対する情報取り込みについて述べる。本手法ではビデ オカメラの有機的な併用も試みており, ビデオカメラの映 像から静止画を抽出し, 画像処理によってモニタリングを 行う研究も進めている。ビデオカメラの映像から 2 枚の静 止画フレームを抽出し, 画像の差分を取ることで変化しな い背景と変化するオブジェクトの分離を行い, 変化するオ ブジェクトのみをバーチャルリアリティ空間に表示するこ とができる。これにより, 突然現れた人間や物のサイズと 位置を分析することができる。

今回の実験では, 解像度 $640 \times 480$ (フレーム速度は毎秒 10 フレーム) でバーチャルリアリティ内の処理画像を更新 するのに約 $600[\mathrm{~ms}]$ を要した。解像度 $640 \times 480$ の背景画像 の寸法が既知であることを利用してオブジェクトの高さ, 横幅の計測も可能であった。測定誤差は, 高さ方向で平均 $3[\mathrm{~cm}]$ 程度, 横幅方向で平均 $5[\mathrm{~cm}]$ 程度となった。図 6 にバ
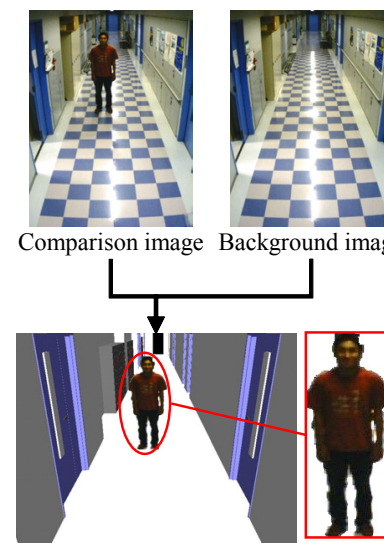

Virtual Reality Space

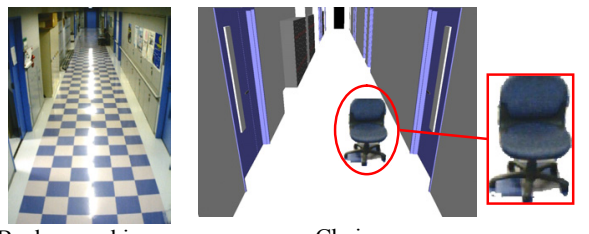

Chair

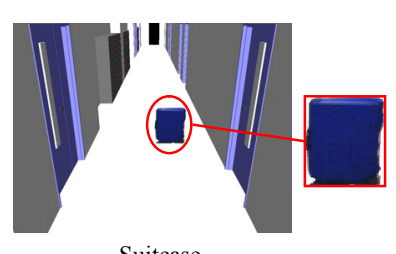

図 6 ビデオカメラ撮像によるオブジェクトの出力結果

Fig. 6. The output result of object by video camera image. 
一チャルリアリティに人間, 椅子, スーツケースのオブジ エクトを生成した結果を示す。

上記は画像処理を含めたビデオ情報の反映といえる。ま た, 画像処理を含まないビデオの動画や音声のストリーミ ング配信においては, 配信時に 6 7 秒程度の時間遅延が発 生した。これらの時間遅れは, ストリーミングサーバ性能, ネットワーク環境に依存する。

単に静止画を反映させる場合は，解像度 $640 \times 480 \cdot J P G$ 形式の静止画を $100[\mathrm{~ms}]$ 間隔で更新することができ, 時間遅 れが比較的少ない表示を行うことができた。

前述したように，本格的なユビキタス環境として本モニ タリング手法を展開するためには, センサやアクチュエー タのインテリジェント化とともに, センサや自律移動ロボ ットなどがバーチャルリアリティを介して互いに協調し合 うための特定の規則が必要となる。

そのような本格的なユビキタス環境となるモニタリング 手法として構築されたとすると, 図 1 におけるインテリジ エントなセンサや自律移動ロボットなどがどの様な知的機 能を果たすか, その可能性について述べる。

あるドアにインテリジェントなセンサが設置されてい る。センサはバーチャルリアリティにアクセスし，そこに 集約されている情報の中からドアの周囲にいる人間や自律 移動ロボットの現在地や認証 ID を取得する。取得した情報 によってドアの前に人間や自律移動ロボットがいることを 認知すると, センサはバーチャルリアリティから自律移動 ロボットの認証 ID を認識し, 正規の認証 ID であればドア を開ける。バーチャルリアリティの情報によってドアを通 過したことの確認を取るとドアを閉める。

このシーンにおいては，ロボットは自身のセンサ情報だ けにたよらず行動していることになる。これだけであれば, 必ずしもバーチャルリアリティである必要は無いが，ユー ザとしての人間の支援連携が望ましい場合もある。例えば, 自律移動ロボットのモニタリングをしている人間が, 自律 移動ロボットの進行方向にいかなるセンサからも検知され ていない突発的な障害物を発見した場合である。この時, 人間はバーチャルリアリティを介して自律移動ロボットに 障害物の情報を配信すると同時に, ロボットの安全な行動 をモニタリングによって確かめられることになる。つまり， 自律移動ロボットは搭載しているセンサでは取得すること ができない情報を人・センサ群との連携支援によって得る ことが可能となる。またこれにより，ロボットへのセンサ 搭載負荷の軽減が可能となるであろう。

\section{4. おわりに}

本研究では, 本システムを用いた幾つかの運用実験を LAN, インターネット（Web）上で行い, システムに要求 されるであろう条件（11)（5)）について性能を確認し，時 と場所を問わないユビキタス性を有するモニタリング・制 御システムとしての機能, 多様性, 有用性について検討を 行った。
本手法によって, 人間, インテリジェントなセンサ群, 自律移動ロボットなどが, バーチャルリアリティを情報共 有のプラットフォームとして, 互いに連携支援し合いなが ら特定の知的機能を果たす本来的ユビキタス環境の実空間 モニタリングへの可能性を見出すことができた。

\section{謝 辞}

本研究において実験システムの構築に協力してくださっ た, 井上雄一氏(現 創価大学大学院工学研究科情報システ 么学専攻在学中)に深く感謝いたします。

(平成 15 年 4 月 7 日受付, 平成 15 年 9 月 18 日再受付)

\section{文献}

（1）リョーイスイエン・前山祥一・油田信一：「移動ロボットの環境認識 過程の WWW ライブ 3D モニタリング」, 第 19 回ロボット学会学術 講演会, pp.647-648(2001)

(2) http://kaiwo.com/kiriicom/EVANGELS/vrml/external_api.html

(3) 舘暲:「バーチャルリアリティ入門」, 筑摩書房 (2002)

（4）三輪建夫・森田秀之:「人工現実間の応用研究と実用化の国際動向」, 日本ロボット学誌，10，7, pp.846-852 (1992-7)

（5）月本 洋:「ロボットのこころ」, 森北出版 (2002)

(6) I. Hara : "Teleoperation System on the Internet", RSJ, Vol.17, No.4, pp.477-480 (1999-4) (in Japanese) 原功:「インターネットを利用した遠隔操作システム」, 日本口 ボット学誌, 17, 4, pp.477-480 (1999-4)

(7) S. Hirai : "Network and Telerobotics", RSJ, Vol.15, No.4, pp.516-519 (1997) (in Japanese)

平井成興: 「ネットワークとテレロボティクス」, 日本ロボット学誌, 15, 4, pp.516-519 (1997-4)

(8) J. Hartman and J. Wernecke : VRML2.0 ハンドブック -Web 上の 世界に動きを一, アジソン・ウェスレイ（1997）

(9) R. Carey and G. Bell : 注解VRML2.0 リファレンスマニュアル, ア ジソン・ウェスレイ (1998)

（10）ジェミー・ジョウォルスキー・ポール・ペローネ : Java2 セキュリ ティプログラミング, ピアソン・エデュケーション (2001)

(11) Elliotte Rusty Harold : Java ネットワークプログラミング第 2 版, オライリー・ジャパン (2001)

（12）トッド・クルトゥワ:Java ネットワーキング\&コミュニケーション , ピアソン・エデュケーション (1998)

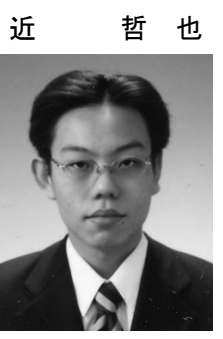

(非会員) 1980 年 2 月 8 日生。 2002 年 3 月創 価大学工学部情報システム学科卒業。現在, 同 大学院工学研究科情報システム学専攻博士前 期課程在学中。

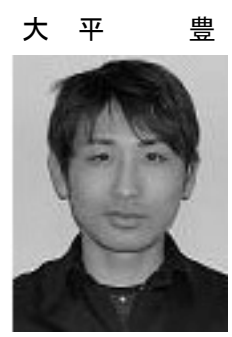

（非会員） 1978 年 7 月 5 日生。 2003 年 3 月創 価大学大学院工学研究科情報システム学専攻 博士前期課程修了。在学中は双方向インタラク ティブ仮想空間システムの研究に従事。現在, 富士ソフト $\mathrm{ABC}($ 株)に勤務。 


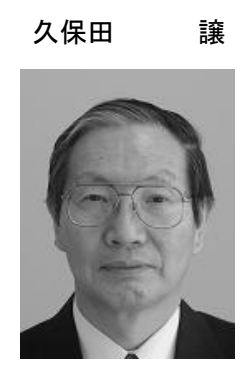

渡 辺 - 弘 (正員) 1953 年 8 月 13 日生。 1976 年 3 月慶 （非会員） 1939 年 7 月 11 日生。 1963 年 3 月 室蘭工業大学工学研究科精密工学専攻博士課 程単位取得退学, 同年室蘭工業大学講師。現在, 創価大学工学部教授。(工学博士)制御, ロボッ 卜挙動等の研究に従事。計測自動制御学会, 日 本機械学会, 日本ロボット学会等の会員。

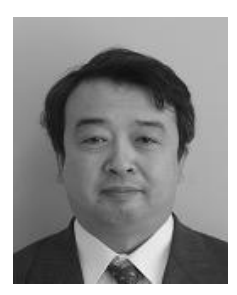
応義塾大学工学部電気工学科卒業。1981 年 3 月同大学院工学研究科電気工学専攻博士課程 修了。現在, 創価大学工学部教授, 同学部情報 システム工学科長。レーザの光情報装置への応 用, 光ファイバセンサ, 自律移動ロボットの自 己位置認識システム等の研究に従事。(工学博 士）計測自動制御学会, 日本ロボット学会, 応 用物理学会, 可視化情報学会等の会員。 